\title{
Colonial Penal De San Ramon: Images of the Oldest Existing National Penitentiary in the Philippines (Circa 1870)
}

\author{
MICHAEL VINCENT P. CACERES \\ mikel_vpc@yahoo.com \\ Universidad de Zamboanga
}

Date Submitted: August 27, 2007

Final Revision Accepted: October 18, 2007

\begin{abstract}
Based on Wilhelm Dilthey's (1833-1911) philosophical inquiry, the study explored the history of the Penal Farm as an Institution - it survived and its role in society amidst political and social pressures. As a historical narrative case study, it looked into the collective efforts in the establishment of the Penal Farm through a careful examination of historiography texts. The study provides basic elements in holding mounting exhibition such as intellectual element, conceptual element and practical element. The study aimed to make the people of Zamboanga fully aware of the preservation, conservation, and restoration of historical landmarks in Zamboanga. A significant finding of this research is the early historical development of San Ramon Penal Colony, reflected in the 1866 order issued by the Spanish government that is today the oldest existing national penitentiary in the country. The research highly recommends the conduct of exhibition for public viewing. The research data were taken/ verified from the Bureau of Corrections (BuCor), National Historical Institute (NHI), National Library of the Philippines (NLP), and the San Ramon Prisons and Penal Farm (SRPPF).
\end{abstract}

Key words - Colonia Penal, penitentiary, prisoners 


\section{INTRODUCTION}

The United Nations Educational, Scientific and Cultural Organization (UNESCO) seek to encourage the identification, protection, and preservation of cultural and natural heritage around the world that is considered to be of outstanding value to humanity. This is embodied in an international treaty called the Convention concerning the Protection of the World Cultural and Natural Heritage adopted by UNESCO in 1972 (http://whc.unesco.org/en/about/). This study on Colonia Penal de San Ramon does not necessarily exemplify man's greatest achievement in architecture and design.

However, its lessons to history cannot be underestimated. In the words of Javier Perez de Cuellar- former secretary general of the United Nations, "The World Heritage Convention also recognizes that we can learn from past mistakes, from places such as Auschwitz, the NAZI death camp in Poland that claimed nearly four million victims during World War II, and Goree Island, a slave trading depot off the cost of Sengal (Our World's Heritage, 1987)." Like any other cultural heritage sites, Colonia Penal de San Ramon must be given equal opportunity in the preservation, conservation and restoration of our cultural heritage as mirror of our past.

According to correctional experts, "Corrections" in the Philippines started in the Pre-Colonial times. The Spaniards formally organized the first correctional system in the country. In Zamboanga, correction was made possible through the Royal Decree, which in 1869 gave birth to Colonia Penal de San Ramon. It was destroyed in 1898 during the Spanish-American war and was rebuit during the American regime.

The San Ramon Prison is a highly recognized national penitentiary. Prisons are known as penitentiary or penal complex (Kransnow 1998); these are living units far larger in area compared to jail. It imposes top-security measures, secures units at all cost, and is secluded away from urban centers. San Ramon Prison houses some of the most celebrated criminal cases in the Philippines and is 22 kilometers away from the city proper.

The urban development in the area without a clear program for heritage conservation threatens its existence. With the creation of Zamboanga City Special Economic Zone (ZAMBOECOZONE) pursuant to RA No. 7903 on July 25, 1994, the area owned by the San Ramon Prison and Penal Farm was designated as part of the ZAMBOECOZONE Freeport Authority pursuant to proclamation No. 111 of President Gloria Macapagal Arroyo and Proclamation No. 112 proclaiming the mountainous and forested area of Upper Bongiao and Curuan as its relocation site. At present, the colony, while awaiting its relocation, produces crops such as cassava, mangoes, vegetables and other cash crops for sale and consumption of prisoners (SRPPF files).

\section{FRAMEWORK}

This study is based on Wilhelm Dilthey's (1833-1911) philosophical inquiry on 
"The Understanding of Other Persons and Their Life Expressions." This philosophy was adopted to trace the origin of San Ramon Penal Farm in Zamboanga. Dilthey's work stresses that if we do not have access to the life of such person, we look at "life expression." This is possible when we search for records in the archives and datable expressions (Hornedo S.N.) involving the person's past statements and actions.

This research looked into the accomplishments of Ramon Blanco and other persons particularly that of the Americans during their occupation in Zamboanga as a collective effort to established the Penal Farm in Zamboanga and the penal system in general. Dilthey's work also concerns with the quality of historical materials used when doing a critical inquiry as this will affect the level of historical and philosophical inquiry. This study explored at the history of the Penal Farm as an Institution - how it survived and its role in society amidst political and social pressures during its early stage and the contemporary period.

This study is arranged into three elements - intellectual, conceptual, and practical - as standard procedure in mounting exhibition. The study begins with the intellectual element, a detailed discussion and analysis of the history of the penal system with emphasis on San Ramon. The discussion covers three significant historical developments from the introduction of punishment and confinement to the current state of the San Ramon Penal Colony and the Correctional Reforms. The conceptual element is a pictorial or graphical presentation of architectural aesthetics, visual arts and scenes. This element demonstrates areas of this cultural heritage that requires conservation, protection and preservation. The pictures serve as the main materials for the exhibition.

\section{OBJECTIVES OF THE STUDY}

This study was conducted in order to: (1) narrate the history of Colonia Penal de San Ramon in Zamboanga with emphasis during the Spanish time to the Post Philippine Independence; (2) document Colonia Penal de San Ramon with emphasis on its architectural aesthetics, visual arts, and scenes that will serve as baseline for the preservation, protection, conservation and restoration of cultural heritage site; and (3) provide procedures in the conduct of mounting exhibition on the San Ramon Penal Colony.

\section{METHODOLOGY}

This is a historical narrative case study based on Wilhelm Dilthey's (1833-1911) philosophical inquiry. As a historical narrative research, it looked into the collective efforts of individuals to establish the Penal Farm in Zamboanga. It laid down the historical facts gathered from the various documents, series of interviews, and fieldwork following a careful examination of historiography texts. The design of this 
study is based on the "Insider's Guide to Mounting Exhibitions" designed by the Ortigas Foundation Library and the Lopez Memorial Museum.

The study provides basic elements in conducting mounting exhibition such as intellectual element, which refers to research and data gathering; conceptual element, which refers to conceptualizing an exhibition particularly choosing the materials for the exhibit; and practical element- gallery design and installation. San Ramon Prison and Penal Farm, situated at San Ramon, Barangay Talisayan, Zamboanga City, is about 22 kilometers away from the city proper, accessible by first class road.

The place is along the coast facing the South China Sea. Originally, it had a total land area of 1,414.68 hectares as defined in the Executive Order No. 47 dated November 19, 1906, of which 500 hectares was transferred to the Philippine Coconut Authority by virtue of Presidential Proclamation No. 1025 dated June 09, 1972, whereby 20 hectares has been occupied by the Western Mindanao State University (WMSU), Zamboanga City, for educational and instructional purposes. Another 250 hectares of squatted land was transferred to the Department of agrarian Reform (DAR) for distribution to CARP beneficiaries in Region IX by virtue of Deed of Transfer between DAR and BUCOR (SRPPF file paper).

\section{RESULTS AND DISCUSSION}

\section{Intellectual Element}

Analyzed based on content, their element focuses on the historical development of penology of San Ramon for mounting exhibition.

Founding of San Ramon

Long before the age of exploration and colonization, prison system was somewhat informal in nature. In the case of the Philippines, it was basically a community-based, since there were no national penitentiaries. Natives who violated the local laws or certain beliefs were given corresponding penalties by the local chieftains. Political leadership was legitimized and supported by sets of custom laws called battasan in some barangays.

Incarceration in the community was only meant to prevent the culprit from further harming the local residents. This system was made up of a complex set of custom laws, which described the range and defined the limits of behavior in society. It was speculated by correctional experts that "the earliest example of classification was Spain's separation of men and women in 1519. While in the United States, the Quakers separated the sexes in the Walnut street Jail of 1790. Children began to be segregated from adults around public juvenile training schools in Massachusetts (1848) and educational programs for juveniles at Elmira Reformatory (1876)."However, correctional experts claimed that "Bridewell" in London in 1557 is the first Penitentiary in history. 
The most concrete documentation of correctional system in the Philippines was the establishment of the main penitentiary, the Old Bilibid Prison in Oroqueta, Manila, which was established in 1847 pursuant to Section 1708 of the Revised Administrative Code. It was formally opened by a Royal Decree in 1865.

This prison was known as the "Carcel y Presidio Correccional" and could accommodate 1,127 prisoners. The Carcel was designed to house 600 prisoners who were segregated according to class, sex, and crime while the Presidio could accommodate 527 prisoners. Following the report prepared by Senator Salvador Laurel in the senate in 1969, the Old Bilibid Prison was the main insular penitentiary designed to house the prison population of the country.

The Philippines has seven national penitentiaries beginning from the first formal correctional inception introduced by the Spaniards. The Old Bilibid Prison now known as the National Bilibid Prison was said to be the first correctional system in the country in 1865. Other penal colony followed such as the Colonia Penal de San Ramon in Zamboanga City (1870), Iwahig Penal Colony in Puerto Princesa (1904), and Correctional Institute for Women in Mandaluyong (1929), Davao Penal Colony (1932), Sablayan Prison and Penal Farm (1932) in Occidental Mindoro, and Leyte Regional Prison (1973).

The penal colony in Zamboanga was made possible because of the Spanish presence primarily in 1598 with the establishment of a fortress in La Caldera, now known as Recodo. “On June 23, 1635, Fray Melchor de Vera laid the cornerstone of Fort Pilar and the Spanish government authorities changed the name of the place from Samboanga to Zamboanga. These two events are marked in history as the founding of the city."

The Old Bilibid Prison in Manila (now the New Bilibid Prison in Muntinlupa) and the San Ramon Prison are the two oldest national penitentiaries in the country. The two penal colonies were both established by the Spaniards, contributing to the historical development of the correctional system in the Philippines. "In 1866 an order was issued by the Spanish government creating a commission to devise means for utilizing convict labor in the Philippines. The plan adopted contemplated a number of penal colonies."In 1869 even as Bilibid was only four years old and capable of holding more, the authorities saw the need of establishing one prison separate from Bilibid for those who fought the established government." Just four years after the Old Bilibid Prison was established, after much deliberation a colony was decided to be set up located on the coast 15 miles north of Zamboanga.

The San Ramon Penal Colony was founded in 1869 and was officially recognized and made known in 1870. San Ramon was founded by the Spanish Government but the American Government later took over after Spain lost the war against the United States. “Esta granja fue establecida por el gobierno español en 1870, pero se encargo de ella el Gobierno Insular poco despues de la ocupacion Americana (The Farm was established by the Spanish government in 1870, but was taken over by the insular government soon after American occupation)." Strengthening the historical claim on San Ramon Penal 
Colony is the presence of the marker that states, Al Ilustre Fundador De Esta Colonia Exmo Senor Teniente General Don Ramon Blanco Y Erenas Marque de Pena Plata 31 Agosto 1870.

The original site of San Ramon had its natural boundaries in Talasayan River (now Talisayan River) on the South, Lubugan River on the north with the high range of mountains on the East and the Pacific Ocean on the West. "Aside from this boundary river Sax (now Sa-az River), which rises far up among the mountains, crosses the immense tract of land and empties its clear, fresh water into the sea through four splendid estuaries. This river is the chief water supply of the colony." The colony faces Jolo Sea, as Spanish-inspired dormitories and originally sat on a 1,414 hectare property. It was on August 21, 1869 that the San Ramon Prison and Penal Farm in Zamboanga City were established under section 1720 of the Revised Administrative Code.

"La Granja Penal de San Ramon, que comprende una extension superficial aproximada de 1,080 hectareas (2,750 acres), se halla situada a unas quince millas (veintidos kilometros) al Nordeste de Zamboanga, la capital de la Provincia Mora (hoy Departamento de Mindanao y Sulu). Teniendo en frente el estrecho de Basilan, extendiendose desde la misma orilla del mar hasta el pie de las montañas, surgiendo en una comarca de profusos bosques tropicales, constituye un paisaje precioso."

"The San Ramon Penal Farm, comprising an area of approximately 1,080 hectares (2750 acres), is located about fifteen miles (twenty-two kilometers) northwest of Zamboanga, the capital of the Moro Province. Fronting the Basilan Straits, extending directly back from the shore to the foothills of the mountains and resting in a region of profuse tropical forest vegetation, it has indeed a beautiful setting."

The San Ramon Penal Colony was established to imprison Muslim rebels and other reluctant political offenders opposed to the Spanish rule. It was constructed in Zamboanga because of the presence of a strong Spanish fortress capable protecting Spanish interest.

"The colony was intended to segregate of political offenders who advocated for reforms and to divert their genius to economic planning and agricultural development of the country. Dr. Jose Rizal who fought for reforms was considered against the government and was sent to Dapitan, which in Zamboanga. They did not want him to further his influence hence he was exiled alone away from San Ramon." The Penal colony in Zamboanga was part of the Spanish grand plan to suppress Islamic believers and those against the conversion of Muslims to Christianity. The Muslims in confinement were significant result both for prisoners and the institution was oriented from fishing to farming. Thus, the Muslims prisoners contributed so much to the agricultural development and scientific experiment in San Ramon.

“La granja se establecio principalmente para los moros y la teoria de su funcionamiento se basa en el estudio de su caracter segun han podido deducirlo gobernantes experimentados de la Provincia Mora. Una de las consideraciones fundamentales para desarrollar el caracter agricola de la 
granja la constituye el hecho de que el moro, ni por instinto, ni por costumbre, es agricultor, y se espera estimular su interes y su actividad en esa direccion, produciendo cada año cierto numero de labradores experimentados y practices. Un factor secundario en la resolucion de crear una prision mora fue la conviccion de que podia llegar a sostenerse por si misma y de este modo descargar de las espaldas de un pueblo no muy rico el peso de mantener a sus penados. Todo el sistema penitenciario se funda en el reconocimiento de que los moros no se han puesto en contacto con las influencias civilizadoras sino en epoca relativamente muy reciente, habiendo sido durante siglos un pueblo barbaro, depredatorio y guerrero, que no tenia del bandolerismo, la pirateria y el asesinato el mismo conceopto que nosotros. Se ha comprendido que deben ser tratados de manera diferente que otras personas de mas avanzado estado moral, y gradualmente educados hasta que tengan del delito el mismo concepto que las gentes que les rodean."

"The Farm was established principally for Moros and its theory of operation was based upon the estimate of their character formed by experienced administrators of the Moro province. One of the prime considerations in emphasizing the farm features was the fact that the Moro was not instinctively nor by practice a farmer, and it was hoped to stimulate interest and activity along this line, each year turning out a certain number of experienced, practical farmers. The second factor in the decision to initiate a Moro prison farm was the conviction that eventually the colony could be made selfsupporting, lifting the burden of supporting convicts from the shoulders of a not so rich a people. The entire prison system was founded to bring the Moros to civil influence. It was realized that the Moros must be dealt with differently from a people of a more advanced moral status, and gradually bring them to an understanding of crime as viewed by their neighbors."The move was intended to ensure that Christianity shall prevail in Zamboanga and eventually penetrate Sulu.

During the Spanish time, a rebel who was not shot was either sent to Guam or Marianas." The founding of Bilibid Prison and Colonia Penal de San Ramon provided the government authorities with alternatives as to the confinement and punishment of convicted criminals and political offenders. The colony played a significant role in materializing Spanish plans in the south and it served as the center of confinement for those against the Spanish rule.

Long before the founding of San Ramon Penal Colony, prisoners were first stationed in Calarian, the present site of Western Mindanao Command (a military camp). The prisoners were later transferred to San Ramon in Talisayan, Zamboanga City. No single item was left in San Ramon to commemorate the Spanish legacy, except the name "Colonia Penal de San Ramon", the very site where it was established, the century old trees in the area, and the celebrated feast for San Ramon Nonato.

San Ramon Penal Colony is considered by correctional experts as the second oldest penitentiary in the country. However, it is also safe to say that it is the oldest existing penal colony in the country after the closure of the Old Bilibid Prison (circa 
1940). Other historical accounts suggest that"San Ramon Prison was established in southern Zamboanga on August 21, 1870, through a royal decree promulgated in 1869. It was established during the tenure of Governor General Ramon Blanco (whose patron saint the prison was named after). The facility was originally established for persons convicted of political crimes. It was also said that "la Institucion estaba destinada al principio a albergar 400 penados (the Institution was originally designed to house 400 prisoners)."

Initial research revealed that San Ramon Farm was named after the patron saint of its founder, making August 31 as the Foundation Day and Feast of Patron Saint Ramon Nonato. Accordingly, San Ramon Nonato was born at Portella, Catalonia, Spain, in 1204; died at Cardona, near Barcelona, Spain, in 1240; and canonized in 1657.

During the Spanish occupation, Zamboanga was the most advanced region in the South. "It was the center of trade and commerce, home of the Mindanao Archdiocese, seat of Spanish culture, capital of political affairs, and base of military operations among others. It was the Leal y Valiente Villa (Loyal and Valiant City), a title conferred upon it by the Spanish Crown in 1872 for the courageous and heroic defense against piracy and other forms of lawlessness."

The Penal Colony struggled for many years, making some progress in experimental work but suffering from mismanagement. Prisoners from Zamboanga were sent out as laborers to the farm. They also set clearing ground near the beach for cultivation or planting. They also built storehouses for the produce when harvested. "For long years San Ramon was destined to be a center of experiments in agricultural and in" Authorities of the Penal Colony soon developed series of agricultural programs.

"Casi toda la instruccion que se da a los presos. Tiene caracter agricola.

Entre los trabajos a que se dedican los presos en la granja se hallan la produccion de copra, un Molino, la cria de credos y vacunos, horticultura, pesca, cesteria y construccion de caminos. Ademas del principal producto agricola, la copra, se cultiva otra gran variedad de productos, como el maiz, la piña, la papaya, el camote, el tabaco, la calabaza, etc., habiendo sido muy natable el buen exito obtenido en estas empresas."

"Practically all the instructions given to the prisoners were along agriculture. The activities of the farm included copra production, gristmill, hog-and stock-raising, horticulture, fishing, basket-making, and road construction. In addition to the chief agricultural product, which was copra, a great variety of other crop were cultivated such as corn, squash, pine-apples, papayas, sweet potatoes, and tobacco.

The authorities saw the success of the Penal Colony not just as a center of confinement but also as a center of the economic development in the region because of its agricultural products and intellectual development due to scientific experiments in agriculture.

"Mas del ochenta y siete por ciento de las raciones totales que se sirven a los presos estan compuestas de productos agricolas. Se ha dedicado especial atencion a la Buena alimentacion, siendo casi ideal la racion que se da, tanto 
por su valor natritivo como por su facil digestion. Se toman extraordinarias precauciones en la preparacion de la comida, para obtener la mayor higiene y salubridad y la ausencia casi total de enfermedades en la granja es una prueba de la minuciosidad de este cuidado y de los satisfactorios procedimientos sanitarios que se practican."

"Over eighty-seven per cent of the total rations issued to the prisoners were composed of farm products. Particular attention was given to proper feeding, the food was nearly ideal in nutritional value. Sanitation was strictly observed as evidenced by absence of ailments among the prisoners.

Due to farming success, the prisoners were treated well by authorities. The colony became the prisoner's found home, newly a place they called iron paradise. The place gave them the promise of an abundant life as "todo el pescado que se usa en la prision es cogido por un peloton de penados rebajados que se interna varias millas en el mar y recorre la costa con este odjecto (All of the seafoods served at the prison were caught by a squad of trusty prisoners who sailed several miles)." Therefore, the notion that those who were confined in San Ramon had miserable life is wrong. To extend their way of living was their lives were far more convenient than those in communities. They were actually given a place of their own and freedom to some extent.

The leadership of Don Felipe Dujioles bought much progress to San Ramon. He was a captain of an Infantry, an agricultural expert being a degree holder in agricultural engineering, and later appointed Director. During his administration, the boundary of the farm was extended until it covered 2,000 hectares."The traces of scientific planning and agricultural growth can still be seen in the way the coconut trees were planted."These trees symbolize the agricultural and scientific progress of San Ramon, reflecting the economic growth of Zamboanga. "In 1883, this captain was given sole charge of the farm, prisoners, and military detachment. When necessary, he could ask appeal to his immediate superior, the Commanding General of Mindanao, for assistance."

\section{Military Leadership of Ramon Blanco}

When Blanco served as military Governor in Mindanao, he continued the campaign against the Muslims. The peak of his military career was when he served as Governor General in the Philippines from 1893 to 1896. In 1896 Blanco was already 63 years old and speculations emerged on how his military leadership was going to be. At the outbreak of the revolution, Gov. Gen. Ramon Blanco faced successive defeats. In a telegram to Madrid, the Dominican archbishop Nozaleda complained on Blanco's apathy as the situation worsened and expressed how necessary the appointment of a new leader. The friars accused General Blanco of his incompetence to handle the situation. The friars rejoiced when Gov. Gen. Blanco was relieved by General Camilo de Polavieja on December 13, 1896. Blanco was later assigned in Cuba as Governor General from 1897 to 1898.

The bombing of the American battleship Maine at Havana Harbor in the evening of February 15, 1898, caused the death of 266 Americans. On April 23, 1898, after 
Liceo Journal of Higher Education Research

consulting the Council of Ministers, Queen Regent Maria Cristina issued a declaration of war against the United States. On April 25, 1989, the US Congress enacted the act that formally declared war.

\section{San Ramon during the American Administration}

In February 1899, Zamboanga took arms against the Spanish rule. "Three months later, on May 18, a ragtag army under the command of General Vicente Alvarez tried to repulse the new enemy but to no avail."San Ramon was closed down during the Spanish-American war when it sustained damage. In 1899, the Spanish rule in the Philippines ceased following its defeat to the Americans. Some 1000 political prisoners in the colonia were freed by the American authorities.46The convicts, many of whom were called "deportados" from other islands, and some were criminals of the worst type and others political offenders, were them liberated. Many remained in the farm as they had been there for many years and had not intended to begin life elsewhere.47During the war, all the buildings, warehouses and other structures were burned to the ground, except the sugar and saw milling facilities. The colony was later re-established by the Americans after the war.

When the American took over in the 1900s, the Bureau of Prisons was created under the Department of Commerce and Police pursuant to the Re-organization Act of 1905 (RA 1407 dated 01 November 1905). It was on November 19, 1906, when American Governor James Smith issued Executive Order No. 47, defining the total land area of San Ramon Farm to cover 1,414.68 hectares. "Not long after the inception of the American occupation, however, all penal institutions were combined for expediency and better efficiency. On October 26, 1905, the Philippine Commission pursuant to the Reorganization Act 1407 combined the Iwahig Penal Colony, the Old Bilibid, and the San Ramon Prison and Penal Farm and placed them under the Bureau of Prisons."

San Ramon, which was destroyed during the Spanish-American War, was reestablished in 1907 by the American administration, making it as a prison farm. "Construidos totalmente con cemento y acero, con techo de teja, los edificios de la Penitenciarfa se hallan distribuidos de tal modo que proporcionan comodidad, ventilacion e hygiene, sin detrimento de las precauciones esenciales en cuanto a la seguridad de los penados y sin perjuicio de la belleza arquitectonica. Los presos estan acomodados en grandes brigadas de cemento, situadas dentro de un muro exterior. La perfecta ventilacion necesaria en los tropicos se obtiene sustituyendo secciones enteras de mamposteria solida con rajas de barras de acero."

"Built entirely of concrete and steel with red tile roofing, the prison structures were so designed as to secure comfort, ventilation, and sanitation without sacrificing essential precautions as to safekeeping of inmates, and without loss of architectural beauty. The Prisoners were housed in large concrete brigades set within an outer wall. The perfect ventilation necessary in the tropics was secured by supplanting whole sections of solid masonry with panels of steel bars."

The construction and restoration of Colonia Penal de San Ramon was given 
attention by the Americans particularly on the protection of its agricultural design. " $E l$ interior de la carcel se halla situado apaciblemente sobre extenso cesped y sendas de grava blanca, dando al sitio la sombra deseada grandes palmeras de cocoteros (The Interior of the prison enclosure was pleasingly laid out in extensive lawns and white gravel paths and great coconut palms giving a desirable shade). It was on January 1, 1915, when San Ramon was placed under the auspices of the Bureau of Prisons and started receiving prisoners from Mindanao.

"La campaña, digna de atencion, que se ha venido realizando durante los ultimos años en los Estados Unidos a favor de la reforma penitenciaria, ha estimulado hasta tal punto el interes publico en esa labor que justifica la publicacion de interesantes datos acerca de un experimento que se ha verificado, en el trato de penados moros, en las Islas Filipinas."

"The agitation for prison reform in the United States during the past few years stimulated public interest in prison work to such an extent as to warrant publication of interesting facts concerning an experiment in the management of Moro prisoners in the Philippine Island."

Under the American insular government, prisoners of the colony were given employment to make them productive. "Some of them remained at their post; others took up land and built homes for themselves, while others wandered away to live without work." Also, during the American administration many changes were introduced to the colony. "The first superintendents preserved the name "San Ramon" and the monument made of bricks in honor and memory of the founder, Lieutenant general Ramon Blanco. This monument was originally erected by the last Spanish Superintendent."During the American administration in San Ramon, Mr. George M. Havice was recognized as the first civilian superintendent appointed by the government in the late 1901. During his administration, many coconut trees were planted, and about 75,000 hemp plants. No record of female inmates was found in San Ramon. However, few foreigners were also incarcerated.

"La mayoria de los penados de San Ramon son moros. Hay ademas algunos paganos, unos cuantos Filipinos cristianos y poquisimos americanos y europeos. Todos los habitants de la poblacion penal son adultos y varones." The majority of the inmates of San Ramon were Moros. There were in addition a few non-Christians other than Moros, a small number of Filipinos, and a very few Americans and Europeans. The entire prison population was adult male."

In 1912, Gen. John Pershing, chief executive of the Department of Mindanao and Sulu, classified the institution as a prison and penal colony and therein confined people sentenced by the courts under his jurisdiction. General Pershing, being the Governor of Mindanao and Sulu, renovated the penal farm and made it again fit for inmates' occupation.

Under Pershing's supervision, several buildings with a capacity of 600 prisoners were constructed. After several years, the colony became practically self-supporting, with 75,000 coconut trees planted at the beginning of Pershing's administration, 
contributing to the colony's self-sufficiency. Aside from coconuts, rice, corn, papaya and other crops were also cultivated. Another remarkable development of the colony in 1912 under Pershing and Dr. Walter H. Dade as superintendent of the farm was the walling of the prisons with iron bars for the confinement of prisoners who were sentenced by the courts of judicial districts of the Moro Province. The development also included the construction of superintendent's quarter, guards' quarter, and other buildings within the prison walls. It was during the American administration that the name San Ramon Prison was placed on the wall at the front gate and the Assistant Superintendent's quarter was built under the administration of Mr. Cooley.

At the close of 1913 when the civil government was established in the Moro Province and named the Department of Mindanao and Sulu, Mr. Frank W. Carpenter became the first civil governor with residence in Zamboanga. The name San Ramon Prison was then changed to San Ramon Penal Farm. It was said that Governor Carpenter and other military governors before him had the authority to pardon prisoners even convicted by the courts in the judicial districts of Mindanao. Jail guards during the American administration were given special privileges and functions.

"Las funciones de la guardia estan a cargo de una compañia de 61 plazas, reculatadas entre los mismos penados y naturals todos del pais. Esta compañia se halla organizada militarmente, efectuandose los alistamientos por un año, facilitandoseles alojamiento y comida y proporcionandose a las familias de los guardias hogares comodos. Algunos guardias prestan servicion en la misma prision y el resto se utiliza para vigilar a los penados que no estan rebajados, en las faenas del campo."

"The guard's function was exercised by an enlisted prison guard company of 61 men, all natives of this country. This company was organized upon a military basis, enlistment being for one year, quarters and subsistence being provided, and the families of guards being furnished comfortable homes. Certain guards were on duty at the prison while other guards serve as trustees in general farm work."

A large number of the prisoners were Muslims; this was of no surprise since the primary purpose of the colony was to confine Muslim rebels and political leaders opposed to the colonial polices during the Spanish rule and even during the American rule.

“En este sentido es interesante notar que el esesinato y el bandolerismo constituyen mas de las dos terceras partes de los delitos por los cuales los moros extinguen condenas, desde diez años de prison hasta cadena perpetua. Es tambien significativo que entre los penados de San Ramon, mas dignos de confianza, se hallan moros cuyos crimenes son, para nosotros, los masodiosos y cuyas sentencias son las mas duras."

"It is interesting to note that murder and brigandage constituted more than twothirds of the crimes for which Moros were sentenced, and that over twenty percent served a sentence of ten years to life. Interventingly, the most trustworthy of the prisoners at San Ramon were Moros whose crimes in our eyes were most heinous and 
whose sentences were the longest."

The large number of prisoners could not be handled by the jail guards. Thus, the American authorities introduced the "trust system". This system involved the natives and most trusted prisoners. Their role was to help jail guards secure the area for possible escape of the prisoners. The system was found to be effective those days. "En caso de fuga de penados (lo que sucede en San Ramon de tarde en tarde) se ha demostrado que el sistema de los rebajados constituye una verdadera ventaja, pues generalmente se envian en persecucion del preso escapado voluntarios rebajados. En algunos casos han seguido su presa hasta el interior de los bosques de Mindanao, demostranto diligencia y conciencia en el desempeño de su mission. En una o dos ocasiones, se han situado a alguna distancia de San Ramon, en comision especial del servicio, rebajados que han encontrado presos fugados, los cuales se habian dedicado a turbar el orden publico, y aunque algunos rebajados han estado prestando tales servicios por espacio de mas de un año, ni en un solo caso los hombres en quienes de ese modo se ha confiado han dejado de cumplir con su deber."

"In the event of escape of prisoners - an occasional occurrence at San Ramon - the trusty system was found to be of real advantage; trusty volunteers are sent in pursuit of the escaped prisoners. In some cases the trustees trailed their quarry through the jungles of Mindanao, and proved diligent and conscientious in the performance of their mission. In one or two instances, the trustees were detailed at some distance from San Ramon to locate escaped prisoners. Although some were detailed for a period extending over a year, not one had failed in his duty."

Zamboanga was the capital of the Moro Province from 1903 to 1913 and from 1914 to 1920; it was the seat of government of the Department of Mindanao and Sulu. Among those who served as governor of the region at one time or another were Leonard Wood, Frank Carpenter and the famous Gen. John "Black Jack" Pershing. Each one held office in some corner of what is now the Zamboanga City Hall."Under the American administration, Zamboanga became the first municipality to be established in Mindanao and continued to be the center of political affairs in the region. On October 12, 1936, Zamboanga was elevated to a city. Nicasio Valderosa was then the first mayor of the city.

The San Ramon marker provides adequate information about the superintendents of San Ramon Prisons beginning in 1912 until the American rule Dr. Walter Dade (19121913) was recognized as the first superintendent of the San Ramon Prisons.

"Aunque utilizada para fines penitenciarios durante algun tiempo, no se hizo gran cosa para convertirla en una verdadera granja hasta 1912, cuando el Dr. W.H. Dade, ahora Director de la Oficina de Prisiones fue nombrado superintendente de la misma. Durante el tiempo de su gestion y principalmente merced al entusiasta apoyo del general John J. Pershing, entonces Gobernador de la Provincia Mora, se construyeron casi todos los edificios, instituyendose los principios fundamentals del actual sistema. El 
actual superintendente, Mr. Joseph B. cooley, fue nombrado en Febrero de 1914 y bajo su direccion el sistema de rebajados se ha mejorado grandemente y se ha chapeado mayor extension de tierra virgen, dedicandola al cultivo, que en cualquier otro periodo anterior."

"Although utilized for prison purposes for some time, little was done toward actual development of the farm features until 1912, when Dr. W.H. Dade (later the Director of the Bureau of Prisons) became superintendent. During his incumbency, largely through the enthusiastic support of General John J. Pershing, then governor of the Moro Province, practically all of the buildings were constructed and the essential features of the present system instituted. Later on, Mr. Joseph B. Cooley was appointed superintendent in February 1914. Under his direction, the trusty system was greatly elaborated and more virgin land was cleared and brought under cultivation than during any other period."

Joseph Cooley (1914-1920) was recognized as the first director of prisons, followed by Ramon Victorio (1920-1921). It was also during the American administration; when the prisoners were classified or graded into classes, second class and first class. The trusty system was also continued and those most trusted were permitted to live outside the prison walls.

“La practica que se sigue usualmente en el manejo de los presos de San Ramon es clasificarlos como de Segunda clase cuando entran en la carcel y pasarlos a primera clase al cumplir el primer semester, con tal que su conducta lo justifique. Despues de un año de sevir en la prision, con tal siempre que se haya demostrado satisfactoriamente que son dignos de confianza, los penados pueden ser escogidos para ser designados como rebajados. Cuando se les rebaja de esta manera quedan practicamente libres de toda vigilanca y pueden ir y venir por la reserva de la Penitenciaria. Algunos rebajados cuidadosamente escogidos obtienen permiso para vivir en la reserva, fuera de los muros de la prision, y hasta se les envia a Zamboanga y otros pueblos cercanos, en actos del servicio."

"The usual practice of handling prisoners at San Ramon was to grade them upon entrance into prison life as second-class prisoners, advancing those to first-class at the expiration of six-months, provided their conduct warrants it. After a year's service, provided that their trustworthiness was satisfactorily demonstrated, the prisoners might select for designation as trustees. When thus made trustees, they were practically free from restraint and free to come and go upon the prison reservation. Certain carefully selected trustees were also permitted to live on the reservation outside the prison walls and were even sent to Zamboanga and other neighboring towns on prison business."

One of the most significant features of trust system other than living outside the prison wall was free education for the prisoner's children. American authorities constructed a school for children of these trustees. The children were taught by the wives of the American authorities assigned in San Ramon.

“Una de las empresas mas dignas de aprecio en la Granja Penal es la 
escuela para los niños de los-presos rebajados. Se ha construido un solido edificio para albergar cincuenta alumnus y dirige las clases la esposa del superintendente, ayudada por la esposa del jefe del personal y por un preso rebajado capaz de enseñar nociones elementales. Estas mujeres nada cobran por sus servicios, pues acometieron este proyecto voluntariamente encontrando su recompensa en la gratitude demostrada por los niños y sus padres."

"A Most worthy undertaking at the Penal Farm was the school for the children of trusty prisoners. A substantial building was been erected to house fifty pupils, and the schoolwork was carried on under the direction of the superintendent's wife, assisted by the wife of the chief clerk and by a trusty prisoner capable of teaching elementary subjects. No charge was asked by these women for their services. They took the project voluntarily, finding their compensation in the gratitude shown by the children and parents."

The advancement of scientific experiments and agricultural development in San Ramon were later on interrupted because of the Japanese invasion in Zamboanga. For a short while San Ramon was managed by the Japanese imperial army.

On the 15th of March 1995, Proclamation No. 551 declared the last week of October and every year thereafter as "National Correctional Consciousness Week" to create public awareness of and participation in the re-integration of prisoners, probationers, and parolees into society as productive and law abiding citizens. The President then issued a proclamation declaring the last week of October as National Correctional Consciousness week. Products of the seven penal farms were put into exhibit and public information campaign to the public.

\section{b. Conceptual Element}

This element refers to the pictorial or graphical presentation of the gathered data. The presentation provides images of the San Ramon Penal Colony for exhibition. The following are the images of the Penal Colony, providing historical documentation. The images reflect the century old Spanish cultural heritage of Architectural Aesthetics on Visual Arts and Scenes that require preservation, conservation, and restoration.

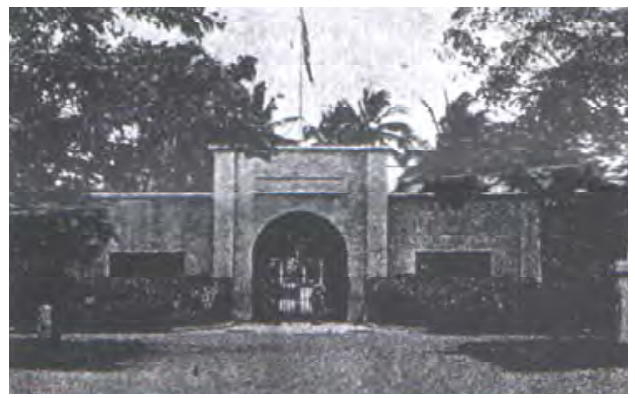

Fig 1 Entrance to San Ramon Penal Colony 
Entrada (Entrance). The San Ramon Penal Farm circa 1900s. Courtesy of the Philippine National Library. La Granja Penal de San Ramon (San Ramon Penal Farm by Dr. C. G. Homson, Assistant Director of Prisons, published by the Philippine Review).

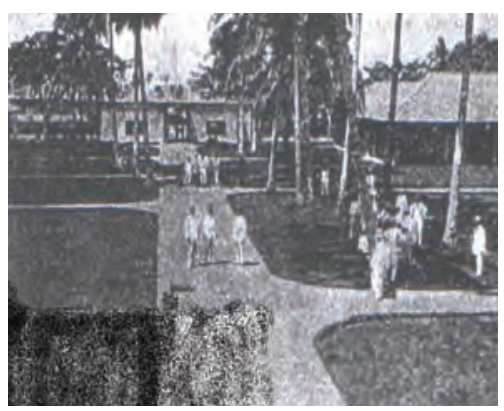

Fig 2 San Ramon Model Buildings

Algunos de los Edificios Modelos (Some of the Model Buildings). The San Ramon Penal Farm circa 1900s. Courtesy of the Philippine National Library. La Granja Penal de San Ramon (San Ramon Penal Farm by Dr. C. G. Homson, Assistant Director of Prisons, published by the Philippine Review).

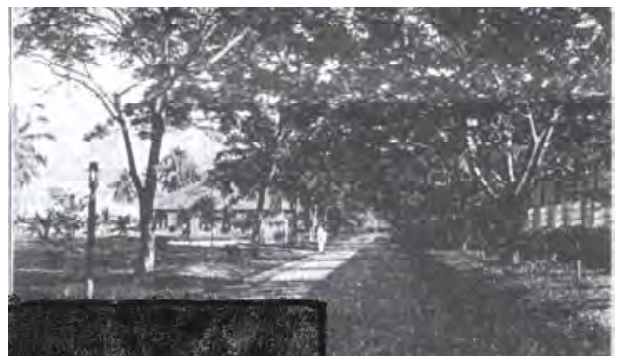

Fig 3 Drives of Farm

Uno de los mas hermosos Pasesos de la Granja (One of the most beautiful Drives of the Farm. The San Ramon Penal Farm circa 1900s. Courtesy of the Philippine National Library. La Granja Penal de San Ramon (San Ramon Penal Farm by Dr. C. G. Homson, Assistant Director of Prisons, published by the Philippine Review).

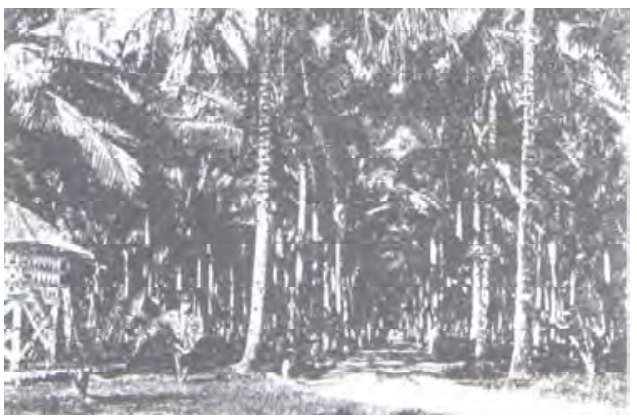

Fig 4 La Granja Penal de San Ramon 
Un producto del trabajo que con tanta eficacia hace del preso un cuidadano mejor (An output of the toil that most effectively makes a better citizen out of a prisoner). The San Ramon Penal Farm circa 1900s. Courtesy of the Philippine National Library. La Granja Penal de San Ramon (San Ramon Penal Farm by Dr. C. G. Homson, Assistant Director of Prisons, published by the Philippine Review).

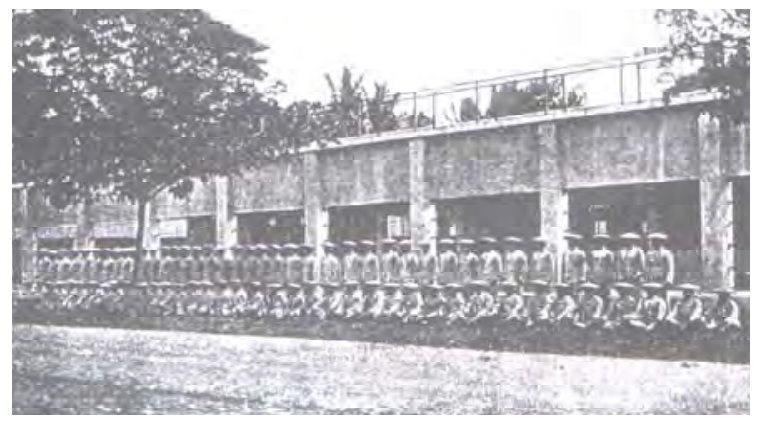

Fig 5 The Prisoners of San Ramon Penal Farm

Los presos (The prisoners). The San Ramon Penal Farm circa 1900s. Courtesy of Philippine National Library. La Granja Penal de San Ramon (San Ramon Penal Farm by Dr. C. G. Homson, Assistant Director of Prisons published by the Philippine Review.

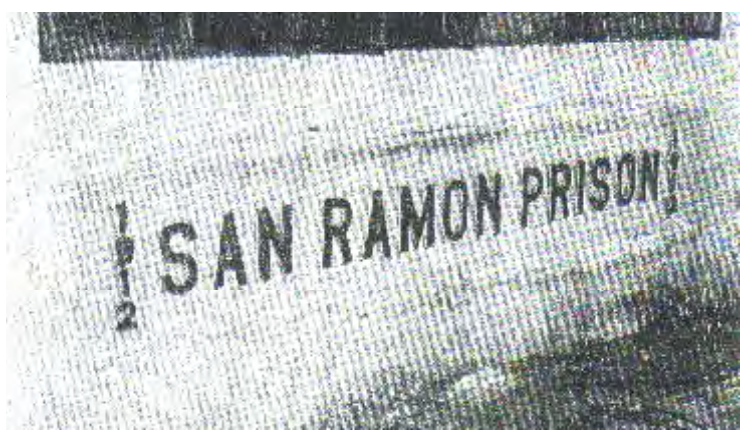

Fig 6 Original Marker

Original Marker of San Ramon Prison and Penal Farm in the Façade of the Administrative Building. Courtesy of San Ramon Prisons and Penal Farm (filed by Armando T. Miranda, Penal Superintendent II). The old San Prison and Penal Farm during the American occupation in Zamboanga circa 1912.

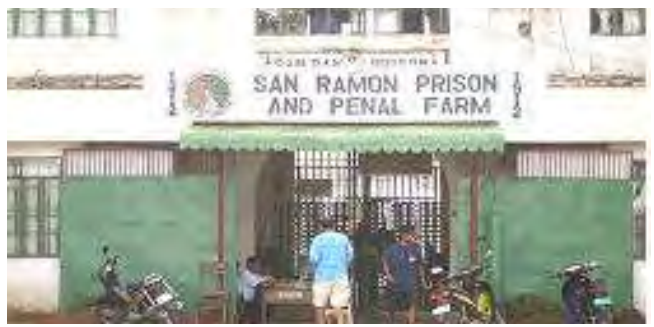

Fig 7 The Old San Ramon Prison 
Current administrative building of the San Ramon and the main gate to the prison cells constructed during the American occupation circa 1912 and had undergone series of renovation and maintains some of its original features, filed by the Universidad de Zamboanga Museum in 2008.

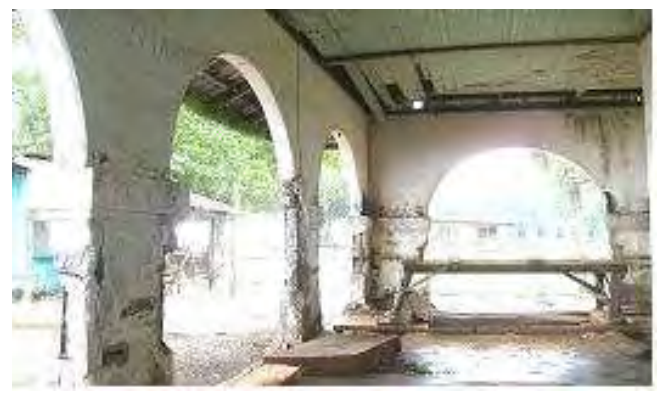

Fig 8 Inner structure of the old quarters

Inner structure of the old quarter of the assistant superintendent constructed during the American occupation circa 1912. It had undergone series of renovation but have maintained some of its original features (filed by the Universidad de Zamboanga Museum in 2008).

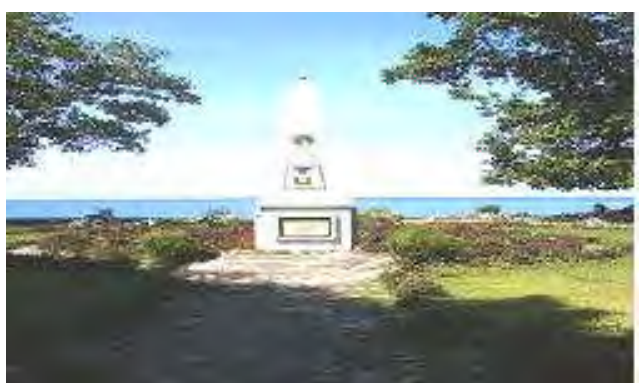

Fig 9 San Ramon marker facing the sea

The San Ramon marker facing the Sulu Sea constructed during the American occupation circa 1912. It has undergone series of renovation but has maintained some of its original features, (filed by the Universidad de Zamboanga Museum in 2008).

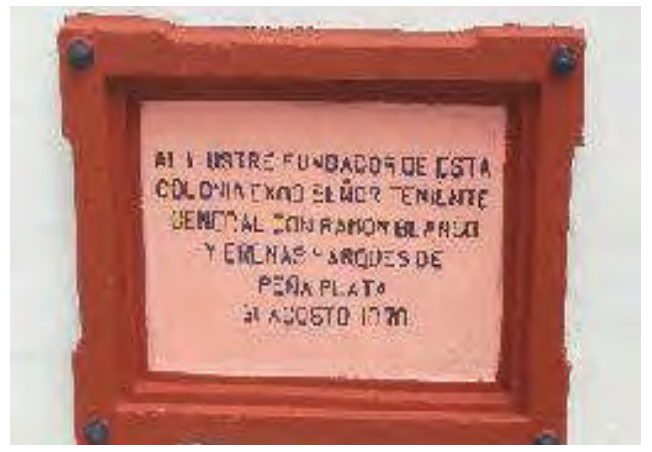

Fig 10 San Ramon fournding marker 
San Ramon marker indicating the founding date 31 August 1870 constructed during the American occupation circa 1912 and undergone series of renovation and maintain some of its original features, filled by the Universidad de Zamboanga Museum in 2008.

\section{c. Practical Element}

This element refers to the installation and proceedings for the exhibition particularly the programme of activities. This is a practical guide needed for the actual exhibition. The following are the areas needed for the mounting exhibition: tools/ materials for the pictorial exhibits, gallery design, installation proper, and the program proper. For better understanding about the standard method used in mounting exhibition, read Running A Museum: A Practical Handbook by UNESCO-ICOM or log on; www.unesco-icom.org.

Tools/ Materials for Mounting Exhibition. These can be materialized by printing shops or digital shops. Decide on the right size of the pictures to be blotted. The following are the possible materials for the pictorial presentation: tarpaulin, pan flex with light, enlarged pictures, and digital pictures.

Gallery Design. A committee will be assigned to look for proper venue where the exhibit will be held. The gallery must be accessible to the public with enough space.

\begin{tabular}{lll}
\hline \multicolumn{1}{c}{ Venue } & \multicolumn{1}{c}{ Dates } & \multicolumn{1}{c}{ Audience } \\
\hline Mall & Week -1 & VIP and Public \\
With-in the University & Week -2 & Teachers and students \\
Penal Farm & Week -3 & Prisoners and staff \\
Traveling/ Roving & Week -4 & As requested \\
\hline
\end{tabular}

Installation Proper. The following needs to be done.

- Prepare panel boards where the pictures can be hanged or attached.

- Observe the proper set-up of the specimen/items to be displayed.

- Observe the audience flow such as the entrance and the exit.

- Check for the lights, ventilation and sound.

Program Proper. This is the opening and closing dates of the exhibit. Identify the needed preparations for the actual exhibition from day one to the last day. The important parts in mounting exhibition is creating committees from research to actual exhibition and preparing the program of activities.

\begin{tabular}{|c|c|c|}
\hline Date of the exhibit & August & Founding day of San Ramon \\
\hline Programme and invitation & A month before the actual opening & See appendix for sample \\
\hline Guest book & c/o secretariat committee & Place at the entrance of the gallery \\
\hline Technical & c/o committee & $\begin{array}{l}\text { Lights, sounds, ventilation, chairs } \\
\text { etc. }\end{array}$ \\
\hline Food & c/o committee & Cocktail \\
\hline Retrieval & c/o committee & $\begin{array}{l}\text { This shall be kept in the library/ } \\
\text { museum/ storage room }\end{array}$ \\
\hline
\end{tabular}


Liceo Journal of Higher Education Research

Committees; Research, Secretariat, Finance, Program, Invitation, Technical and Retrieval Sample Program/ Activity; Invocation, National Anthem, Welcome Address, Inspirational Message, Cutting of the Ribbon, Tour (with guided information), Refreshment and Open Forum (If necessary).

\section{CONCLUSIONS}

This research highlights the importance of a cultural heritage site such as the Colonia Penal de San Ramon. It conveys to the local residence of Zamboanga the importance of the history of the colony in the development of Philippine penology. The paper encourages all concerned individuals to preserve, conserve, and restore this century-old historical site. The founding of San Ramon Colony on August 21, 1869 , is a clear indicator of Zamboanga's strategic position in the Philippine political arena during the Spanish occupation. The data provided and verified by the Bureau of Corrections (BuCor), National Historical Institute (NHI), and the San Ramon Prisons and Penal Farm (SRPPF) strengthen the fact that San Ramon is indeed one of Spain's greatest legacy in 1870, and its maintenance by the Americans in 1901 establishes the idea that Zamboanga has a penal institution.

The photos taken from the field are important source of documents on the history of the penal farm, serving as living witnesses to this century-old legacy. The mounting exhibition will encourage the general public to help conserve, restore, and measure the heritage sites.

\section{LITERATURE CITED}

Agoncillo, T. \& Guerrero, M.C. (1977). History of the Filipino people 6th edition. R. P. Garcia Publishing Co., Q. C. San Ramon Prison and Penal Farm (SRPPF). Filed documents.

Alvor, M. \& Baguilod, B.(SN). Citation as supra "the Philippine corrections system: current Situations and Issues". P. 75.

Barnes and Teeters see Carney, Louis P. (1974). Introduction to correctional science. McGraw-Hill Company, New York. P.80

Bureau of Corrections. Department of Justice (DOJ). Muntinlupa, Philippines (2008) Filed documents.

Caceres, M. V. P. (2008). El centenario: the life story of Engr. Arturo Francisco Eustaquio founder of Zamboanga A. E. Colleges/ Universidad de Zamboanga. Pp.5456

Carney, L.P. (1974). Introduction to correctional science. McGraw-Hill Company, New York. pp. 12, 26, 27, 31-32, 79-82, 92

Carter, R.M., Glasser, D. \& Williams, L.T. ed. (1977). Correctional institutions Second Edition. JB Lippincott Company, Philadelphia. pp.5, 6

Commission on Human Rights (CHR). The situation of the Philippine penitentiaries: 
an update on the study on the conditions of jails and correctional institutions in the country.

Estipona, C. C. (2008). Officer in-charge of San Ramon. Interviewed on August 21.

Eustaquio, R.F. (2007) Narrative Interview. At Residence, Estrada street, Tetuan, Zamboanga City.

Fox, V. \& Stinchcomb, J.B. (1994). Introduction to corrections. Fourth Edition. Prince Hall Career and Technology, New Jersey. pp. 96-99, 101-111, http://www.doj. gov.ph/Historical\%20Background.html/accessed August 20, 2008,

Guerrero, L. M. (1969). The First Filipino. Manila. Pp.373-404.

Hardy, R.E. \& Cull, J.G. (1973). Introduction to correctional rehabilitation. Second Edition. Illinois. pp. 4-5.

Homson, C. G. (SN). La granja penal de San Ramon. The Philippine Review courtesy by NLP.

Jocano, F.L. (1998). Filipino Prehistory: Rediscovering pre-colonial heritage. Punland, pp.162, 192.

Keve, P. W. (1981). Corrections. John Wiley and Sons, USA. No page number

Krasnow, P. (1998). Correctional facility design and detailing. McGraw-Hill, New York.

La Solidaridad (1894). See, La Solidaridad: Quencinario Democratico Vol. VI, June 15, 1894 translated by Guadalupe Fores-Ganzon, Fundacion Santiago, Philippines @ 1996. P. 254

Ocampo, A. Reply letter to the researcher dated July 14, 2008. National Library of the Philippines (NLP).

Orendain, A.E. II ed. (1984). Zamboanga hermosa: memoirs of the old town. Filipinas Foundation, Inc., Mandaluyong. P. 87. National Historical Institute (NHI).

Schmallger, F. \& Smykla, J.O. (2001). Corrections in the 21st Century. McGraw Hill, New York. Pp.64-79, 93.

Sue, T.R. (1981). The correctional system: an introduction. New York. pp.27, 53-54, 147.

White, W. (s.n.). The Government farm at San Ramon." Paper: 23rd Asian and Pacific Conference of Correctional Administrators" P.1.

Zaide, G. \& Zaide, S. (1990). Documentary sources of Philippine History. National Bookstore, Manila. Footnote P. 6, 93, 101. 